Crop Breeding and Applied Biotechnology 14: 94-101 2014

Brazilian Society of Plant Breeding. Printed in Brazil

\title{
ARTICLE
}

http://dx.doi.org/10.1590/1984-70332014v14n2a17

\section{Selection of coffee progenies for resistance to nematode Meloidogyne paranaensis in infested area}

\author{
Sonia Maria Lima Salgado ${ }^{1}$ Juliana Costa de Rezende ${ }^{1}$ and José Airton Rodrigues Nunes ${ }^{2 *}$ \\ Received 06 December 2012
}

Accepted 16 August 2013

\begin{abstract}
The purpose of this study was to select Coffea arabica progenies for resistance to M. paranaensis in an infested coffee growing area using Henderson's mixed model methodology. Forty-one genotypes were selected at the Coffee Active Germplasm Bank of Minas Gerais, and evaluated in regard to stem diameter, number of plagiotropic branches, reaction to the nematode, and yield per plant. There was genetic variability among the genotypes studied for all the traits evaluated, and among the populations studied for yield and reaction to the nematode, indicating possibilities for obtaining genetic gains through selection in this population. There was high rate of genotypic association between all the traits studied. Coffee plants of Timor Hybrid UFV408-01 population, and $F_{3}$ progenies derived from crossing Catuai Vermelho and Amphillo MR 2161 were the most promising in the area infested by M. paranaensis.
\end{abstract}

Key words: Coffea arabica, breeding, additive genetic value, correlation, root knot nematode.

\section{INTRODUCTION}

Among the factors that limit the growth and production process of coffee plant, species of Meloidogyne stand out. Economic losses due to root knot nematodes vary considerably depending on the species involved and their distribution (Boisseau et al. 2009). M. paranaensis is considered more harmful to coffee plant due to high root damage, and may lead to plant death. In face of the occurrence of $M$. $p a$ ranaensis in coffee crops in the state of Minas Gerais (Castro et al. 2008), and the risks of its spread, the identification of genotypes that are resistant and adapted in infested areas is of great importance in a breeding program.

The resistance mechanism of the plant prevents the nematode from developing and/or leads to low reproduction rates. Consequently, in addition to the parasite not causing damage to the crop, the use of genetic resistance also leads to reduction of nematode population density in the soil, and the possibility of economic maintenance of the crop in infested areas.

Some interspecific hybrids between $C$. arabica and $C$. canephora were resistant to $M$. paranaensis, but still seg- regate this resistance (Mata et al. 2002, Sera et al. 2004). Advances in research are made difficult by the perennial condition of this crop and the period of time required for evaluating the behavior of plants derived from sources of Coffea spp. germplasm in an infested area. In fact, under Brazilian conditions, little research has been carried out to study the performance of resistant plants under field conditions. On the other hand, many studies (Ribeiro et al. 2005, Sera et al. 2007, Sera et al. 2009, Ito et al. 2008, Boisseau et al. 2009) have been carried out under greenhouse conditions. Nevertheless, evaluation of genotypes of coffee plant under the conditions of an infested area in the field allows better knowledge of plant behavior and verifies the stability of plant reaction (Alpizar et al. 2007).

In this case, the use of accurate selection procedures becomes essential. Progeny testing has been used in estimating genetic parameters and selection of individuals when one seeks to evaluate the magnitude and nature of genetic variance available with a view toward quantifying, and maximizing genetic gains using adequate selection procedures (Costa et al. 2010).

\footnotetext{
${ }^{1}$ Empresa de Pesquisa Agropecuária de Minas Gerais (EPAMIG), Unidade Regional do Sul de Minas, Campus da UFLA, s/n, C.P. 176, 37.200-000, Lavras, MG, Brazil

${ }^{2}$ Universidade Federal de Lavras, Departamento de Biologia, C.P. 3037, 37.200-000, Lavras, MG, Brazil. *E-mail: jarnunes@dbi.ufla.br
} 
Nevertheless, selection based on inadequate biometric procedures may lead to confounding between genotypic and environmental effects, resulting in low efficiency in selection. The mixed models methodology (Henderson 1984) is a flexible procedure for obtaining estimates of genetic parameters and prediction of breeding values, especially under imbalanced conditions, maximizing genetic gains from selection (Furlani et al. 2005, Chiorato et al. 2008).

The purpose of this study was to select superior Coffea arabica progenies in regard to resistance to M. paranaensis in an infested area using the Henderson's mixed models methodology.

\section{MATERIAL AND METHODS}

Progenies in generation $\mathrm{F}_{3}$ and $\mathrm{F}_{4}$, developed in the Coffee Genetic Breeding Program in Minas Gerais, coordinated by EPAMIG (Crop and Livestock Research Company of Minas Gerais), were selected in the Active Germplasm Bank maintained at the EPAMIG Experimental Farm in the municipality of Patrocínio/MG. Forty-four genotypes were evaluated in the experiment (Table 1). Forty-one progenies belonging to 20 populations, and three Coffea arabica cultivars checks, (i.e. Mundo Novo 379/19 and
Catuaí IAC-64 as susceptible checks and the C. arabica cv. IPR 100 as resistant check) were evaluated (Table 1).

The experiment was carried out in an infested area by Meloidogyne paranaensis, located in the municipality of Piumhi (202 $25^{\prime} 28.7^{\prime}$ ' S, 46 $1^{\circ}$ ' $10.5^{\prime}$ ' W, 812m asl), MG, with annual average temperature of $20.7^{\circ} \mathrm{C}$, annual average rainfall of $1426.3 \mathrm{~mm}$, soil with clayey texture and flat terrain. Identification of the species M. paranaensis in the infested area was carried out using the Carneiro and Almeida (2001) technique.

A randomized complete block design with three replications and spacing of $3.00 \times 0.80 \mathrm{~m}$ was used, with plots consisting of seven plants. Crop treatments performed were those recommended for the coffee crop in the region, with the exception of application of chemical products for nematode control.

Soil samples were collected in the rhizosphere of coffee plants at two months after sowing. In a greenhouse, samples of approximately $2000 \mathrm{~g}$ from each experimental plot were distributed in three-liter capacity pots where two Santa Clara cv. tomato seedlings were planted for biological indicator test of $M$. paranaensis population in the soil of the plots. Evaluation of the test was carried out by means

Table 1. Numerical identification (NI) and generation (G) of progenies originating from the Coffee Active Germplasm Bank at the EPAMIG Coffee Plant Breeding Program, and check cultivars of Coffea arabica evaluated

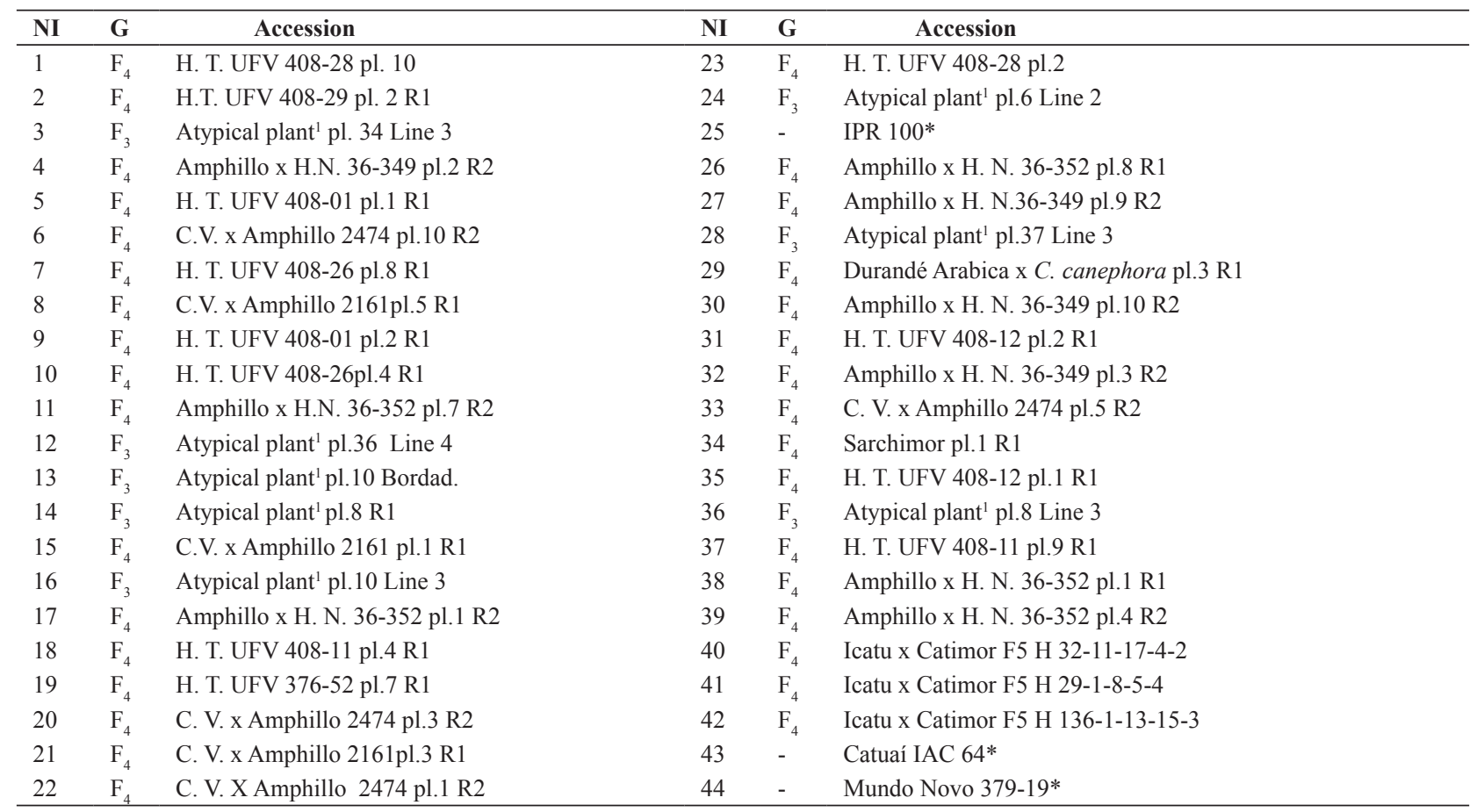

${ }^{1}$ Atypical plant $=$ natural cross between Coffea arabica $\mathrm{x}$ diploid species. ${ }^{*}$ Check cultivars. H.N. $=$ Natural Hybrid.

C.V. $=$ Catuai Vermelho. H.T. $=$ Timor Hybrid. 
of quantification of the number of galls and eggs of $M$. paranaensis in the roots of tomato plants at 70 days after planting. These data were submitted to analysis of variance with the $\mathrm{F}$ test at $5 \%$ of significance (Table 2).

At 18 months from planting, the following traits were evaluated: stem diameter, number of plagiotropic branches, reaction of the genotypes to the nematode, and yield in liters of fresh coffee fruits per plant in the first harvest of 2011. Stem diameter was measured at $10 \mathrm{~cm}$ above the base of the stem, in millimeters, with the aid of a digital caliper rule. The number of plagiotropic branches was calculated by counting of all the primary lateral branches with a size greater than $5 \mathrm{~cm}$. The reaction of genotypes to the nematode was performed following the scale adapted by Carneiro (1995), considering only the above ground part of the plants. On this scale, extremely debilitated or dead plants were given a score 0 . Score 1 was given to plants with severe leaf loss aspect and few leaves; 2 for plants with moderate leaf loss aspect, with small, malformed and stopped leaves, with typical symptoms of nutritional deficiency and accentuated shedding of leaves; 3 for plants of good vigor, with no leaf loss aspect and yellowing, and 4 for plants with great vigor, with no symptoms of parasitic activity. Values less than 3 indicate symptoms of parasite activity by nematodes.

Data were analyzed according to the following mixed linear model in the matrix form (Resende 2002)

$$
y=X r+Z a+W p+T s+e,
$$

where: $y$ : data vector; $r$ : vector of the fixed effects of blocks added to the general average; $a$ : vector of the individual additive genetic effects, $a \sim N\left(0, A \sigma_{a}^{2}\right)$, being $A$ the additive relationship matrix, and $\sigma_{a}^{2}$ the additive variance; $p$ : vector of the plot effects, $p \sim N\left(0, I \sigma_{p}^{2}\right)$, being $I$ the identity matrix, and $\sigma_{p}^{2}$ the variance among plots; $s$ : vector of the population effects, $s \sim N\left(0, I \sigma_{s}^{2}\right)$, being $\sigma_{s}^{2}$ the variance among populations; $e$ : vector of residual errors, $e \sim N\left(0, I \sigma_{e}^{2}\right)$, being $\sigma_{e}^{2}$ the residual variance; $X, Z, W$ and $T$ : incidence matrices for $r, a, p$ and $s$ effects, respectively.

Estimates of genetic parameters were obtained by the REML/BLUP (Restricted Maximum Likelihood / Best Linear Unbiased Prediction) procedure with the aid of the software SELEGEN-REML/BLUP (Resende 2007).

Based on estimates of the components of variance, it was estimated selective accuracies, individual heritabilities and other coefficients of determination associated with the random effects of the model, as well as the genetic, environmental and relative variation coefficients, as described in Resende (2002). Variance components were submitted to likelihood ratio test at 5\% probability (Resende 2007). Genotypic correlations between traits were obtained by Genes software (Cruz 2006).

\section{RESULTS AND DISCUSSION}

All the plots showed a high and statistically homogeneous dispersion of $M$. paranaensis, which was expressed by the number of galls and eggs per root system, and number of eggs/g of tomato root (Table 2). This fact is essential for evaluating progenies in field experiments when the aim is centered in measuring the resistance to nematodes.

The likelihood ratio test revealed the existence of genetic variability among the genotypes studied for all the traits evaluated. In the same way, variability was detected among the populations studied for the fresh fruit yield and reaction of genotypes to the nematode traits (Table 3). The estimates of genetic and phenotypic parameters for the traits evaluated were compatible with other studies in coffee progenies (Freitas et al. 2007, Petek et al. 2008).

All the traits studied were highly influenced by the environment. The individual heritability values in the narrow sense were low, ranging from 4.84 to $14.12 \%$ (Table 3 ). The observed values of the coefficient of determination ranged from $7.14 \%$ to $21.28 \%$ due to the common environment of the plot that quantifies the environmental variability within the plot, which are compatible with experiments considered as precise (Resende et al. 2001, Freitas et al. 2007).

The relative coefficient of variation presented median values for the number of plagiotropic branches and fresh fruit yield ( 0.81 and 0.92 , respectively) showing that selection of the best progenies may increase the genetic value of the population possibly in regard to these traits (Vencovsky 1987). The other traits showed low values for the relative

Table 2. Summary of analysis of variance of the biological indicator test in the area infested by Meloidogyne paranaensis

\begin{tabular}{|c|c|c|c|c|}
\hline \multirow{2}{*}{ Source of Variation } & \multirow{2}{*}{ df } & \multicolumn{3}{|c|}{ Mean Square } \\
\hline & & Number of eggs & Number of galls & Number of eggs/g root \\
\hline Blocks & 2 & - & - & - \\
\hline Genotypes & 43 & $39204622^{\text {ns }}$ & $28920.4^{\mathrm{ns}}$ & $302598.5^{\mathrm{ns}}$ \\
\hline Error & 86 & 36521472 & 29124.778 & 291323.89 \\
\hline Mean & & 6033 & 227 & 553 \\
\hline
\end{tabular}

${ }^{\mathrm{ns}}$ not significant by the $\mathrm{F}$ test (5\%). 
Table 3. Estimates of genetic and phenotypic parameters related to reaction of the genotypes to the nematode (NEM, grade), stem diameter (SD, $\mathrm{mm}$ ), number of plagiotropic branches (NPB), and fresh coffee fruits yield in the first harvest (YIELD, liter plant ${ }^{-1}$ ), through evaluation of coffee plant progenies from different populations at 18 months after planting

\begin{tabular}{|c|c|c|c|c|}
\hline Parameter & NEM & SD & NPB & YIELD \\
\hline$\sigma_{a}^{2}$ & $0.0552 * *$ & $3.0195 * *$ & $6.7091 *$ & $0.3014 * *$ \\
\hline$\sigma_{p}^{2}$ & $0.2427^{* *}$ & $5.9118 * *$ & $5.4737 *$ & $0.1523^{*}$ \\
\hline$h_{a}^{2}$ & 0.0484 & 0.0854 & 0.1371 & 0.1412 \\
\hline$c_{p}^{2}$ & 0.2128 & 0.1672 & 0.1118 & 0.0714 \\
\hline General mean & 2.2206 & 13.7014 & 16.1179 & 0.6892 \\
\hline
\end{tabular}

**," Significant at $1 \%$ and at $5 \%$ respectively by the likelihood ratio test. Additive genetic variance $\left(\sigma_{a}^{2}\right)$, environmental variance among plots $\left(\sigma_{p}^{2}\right)$, genetic variance among populations $\left(\sigma_{s}^{2}\right)$, individual heritability in the narrow sense $\left(h_{a}^{2}\right)$, coefficient of determination of the plot effects $\left(c_{p}^{2}\right)$, and relative coefficient of variation $\left(C V_{r}\right)$.

coefficient of variation ( 0.40 and 0.57 , respectively) manifesting the difficulty of selecting superior plants based on the reaction of genotypes to the nematode trait and stem diameter at 18 months after planting (Table 3).

Number of plagiotropic branches and yield were chosen as major characteristics for selection of individual plants, once these characteristics have shown higher coefficient of relative variation. Also productivity is a major criterion for coffee plants selection (Gichimu and Omondi 2010, Cilas et al. 2011). Another selection criterion was the reaction to nematode, which was determined in plants at 18 months after planting, aiming the identification of nematode resistant plants.

Genetic gain is inversely proportional to the intensity of selection, which quantifies the number of selected individuals (Cruz and Carneiro 2003). Therefore, in this study, the need for working with a greater number of individuals (selection intensity of 5\%) was considered to ensure an effective size that, according to Rocha et al. (2009), allows greater efficiency in the following steps of selection.

Predicted mean with the selection of the 20 individuals (Table 4) based on fresh fruit yield was 2.21, being this value $125 \%$ greater than the general mean value in the yield of all the plants evaluated in the experiment. Plants with greater yield also proved to have greater reaction to nematode grades. Therefore, the reaction of these plants may be resistance or tolerance to $M$. paranaensis since, according to Roberts (2002), resistant plants affect diverse phases of the life cycle and of parasitism of the nematode, restricting or preventing its multiplication, while plants considered to be tolerant allow multiplication of the nematode in their roots without harming yield. It is worth highlighting that in taking into account the initial development of plants, root samples were not collected for quantification of $M$. paranaensis population.
It was observed that the individuals of progeny $15(\mathrm{Ca}-$ tuai Vermelho x Amphillo 2161 pl.1 R1) were predominant among the most promising, with expressive predicted additive genetic values ranging from 2.22 to 2.60 for the reaction to nematode, from 0.68 to $2.21 \mathrm{~L} \mathrm{plant}^{-1}$ for yield, and from 16.11 to 19.92 for number of plagiotropic branches, and constitute 13 of the 20 best classified genetic materials, suggesting good possibilities for genetic progress in the sequence of evaluations in more advanced generations.

Progeny 15, as well as progenies 21 and 22, from which were selected two and one plants, respectively, refers to the $\mathrm{F}_{4}$ generation of the population derived from the cross between Catuaí Vermelho and Amphillo MR 2161. In the same way, Gonçalves et al. (1996) observed partial resistance of the variety Amphillo to race 2 of $M$. incognita; however, for M. paranaensis, this genotype had not yet been studied. Plant six, from the third block of progeny 15 stood out with the yield of $7.00 \mathrm{~L} \mathrm{plant}^{-1}$, a nematode grade of 4.00 , and 28 plagiotropic branches with predicted additive genetic values of 2.63, 2.61 and 19.98, respectively.

Another promising progeny, of which four of the 20 best classified plants were selected, was the progeny 5 , which refers to the Timor Hybrid UFV 408-01. This interspecific hybrid derived from a possible spontaneous crossing of Coffea arabica L. and Coffea canephora Pierre ex A. Froehner constitutes a source of genetic diversity for the development of new cultivars, which have presented promising yields, together with resistance to the agent which causes rust and to the nematode M. exigua (Ribeiro et al. 2005, Carneiro et al. 2008).

With the selection of the 20 best individuals, the initial yield of the population of $0.68 \mathrm{~L} \mathrm{plant}^{-1}$ (Table 3) would increase after one selection cycle to $2.21 \mathrm{~L} \mathrm{plant}^{-1}$ (Table 4). Considering an average yield of 480 liters of fresh coffee fruit for each $60 \mathrm{~kg}$ bag of processed coffee, yield would 
increase from 4.05 to 13.15 bags ha $^{-1}$. These results denote that the selection of plants in this population in an area infested by M. paranaensis is quite promising.

In this study, resistance or tolerance reaction to the $M$. paranaensis nematode was observed in C. arabica coffee plants derived from Catuaí Vermelho x Amphillo MR 2161 and Timor Hybrid UFV 408-01. In other studies, sources of resistance were also identified, including some cultivars being identified as resistant to M. paranaensis. Arabica coffee cultivars IPR 100 (“Catindu”) and IPR 106 (“Icatu”), both developed by IAPAR and susceptible to rust (Sera et al. 2010), show simultaneous resistance to nematodes M. paranaensis and some races of $M$. incognita (Sera et al. 2007, Sera et al. 2009, Ito et al. 2008, Kanayama et al. 2009). 'Icatu Vermelho IAC 3888' (Gonçalves and Silvarolla 2007) and other "Icatu" progenies (Mata et al. 2002, Sera et al. 2004) were also resistant to M. paranaensis. Selections from "Icatu", such as line 925, have shown good resistance to $M$. paranaensis (Matiello et al. 2010). In some accessions of $C$. arabica from Ethiopia, resistance to M. paranaensis was observed (Anthony et al. 2003, Boisseau et al. 2009).

Table 4. Estimates of mean components: Individual phenotypic value (f); predicted additive genetic value ( $\hat{\mathrm{u}}+\hat{a})$; predicted additive genetic gain and predicted bred mean value of the 20 best individuals of the experiment in 41 progenies of Coffea arabica, in an area infested by M. paranaensis, selected for the fresh fruit yield of the first harvest (YIELD, liter/plant ${ }^{-1}$ ); reaction of the genotypes to the nematode (NEM, grade); and number of plagiotropic branches (NPB)

\begin{tabular}{|c|c|c|c|c|c|c|c|c|}
\hline \multirow{2}{*}{ Progeny } & \multirow{2}{*}{ Block } & \multirow{2}{*}{ Plant } & \multicolumn{2}{|l|}{ NPB } & \multicolumn{2}{|l|}{ NEM } & \multicolumn{2}{|c|}{ YIELD } \\
\hline & & & f & $\hat{\mathbf{u}+\mathbf{a}}$ & f & $\hat{\mathbf{u}}+\mathbf{a}$ & f & $\hat{\mathbf{u}}+\mathbf{a}$ \\
\hline 15 & 3 & 6 & 28 & 19.98 & 4 & 2.61 & 7.0 & 2.63 \\
\hline 15 & 1 & 6 & 27 & 19.97 & 4 & 2.61 & 5.9 & 2.54 \\
\hline 15 & 3 & 5 & 24 & 19.60 & 4 & 2.61 & 6.0 & 2.53 \\
\hline 15 & 1 & 7 & 24 & 19.68 & 4 & 2.61 & 4.5 & 2.39 \\
\hline 15 & 1 & 5 & 23 & 19.59 & 4 & 2.61 & 4.4 & 2.38 \\
\hline 5 & 2 & 6 & 28 & 22.23 & 4 & 2.87 & 6.0 & 2.22 \\
\hline 21 & 2 & 6 & 27 & 18.56 & 4 & 2.61 & 7.0 & 2.18 \\
\hline 15 & 2 & 4 & 23 & 19.71 & 3 & 2.61 & 2.0 & 2.17 \\
\hline 15 & 1 & 3 & 20 & 19.3 & 3 & 2.59 & 2.25 & 2.15 \\
\hline 5 & 3 & 2 & 27 & 22.12 & 4 & 2.86 & 5.0 & 2.14 \\
\hline 15 & 3 & 3 & 19 & 19.13 & 3 & 2.59 & 1.5 & 2.05 \\
\hline 15 & 2 & 5 & 19 & 19.33 & 1 & 2.55 & 0.5 & 2.02 \\
\hline 15 & 2 & 3 & 18 & 19.24 & 2 & 2.58 & 0.4 & 2.01 \\
\hline 21 & 1 & 5 & 23 & 18.24 & 4 & 2.61 & 5.0 & 1.99 \\
\hline 22 & 1 & 2 & 26 & 18.20 & 4 & 2.60 & 5.5 & 1.94 \\
\hline \multicolumn{3}{|c|}{${ }^{1}$ New mean value } & 24.25 & 19.92 & 3.50 & 2.60 & 4.02 & 2.21 \\
\hline \multicolumn{3}{|c|}{${ }^{2}$ Predicted gain (\%) } & & 23.64 & & 17.11 & & 125 \\
\hline \multicolumn{3}{|c|}{ Mean value of the progenies } & & 16.11 & & 2.22 & & 0.68 \\
\hline \multicolumn{3}{|c|}{ Mean value of IPR 100} & & 23.25 & & 2.89 & & 3.04 \\
\hline \multicolumn{3}{|c|}{ Mean value of 'Catuaí 64' } & & 15.1 & & 2.11 & & 0.41 \\
\hline
\end{tabular}

${ }^{1}$ Mean value of selected plants, ${ }^{2}$ Predicted additive genetic gain (\%).

Table 5. Genotypic correlation among the traits fresh fruit yield of the first harvest (liter plant ${ }^{-1}$ ), stem diameter (mm) (SD), number of plagiotropic branches (NPB) and reaction of the genotypes to the nematode (grade) (NEM) evaluated in coffee plant progenies at 18 months after planting

\begin{tabular}{lllll}
\hline Traits & YIELD & SD & NPB & NEM \\
\hline YIELD & 1.00 & $0.82^{* *}$ & $0.78^{* *}$ & $0.78^{* *}$ \\
SD & & 1.00 & $0.87^{* *}$ & $0.94^{* *}$ \\
NPB & & & 1.00 & $0.79^{* *}$ \\
NEM & & & 1.00 \\
\hline
\end{tabular}

*** Significant at $1 \%$ of probability by bootstrap sampling. 
Some authors emphasize the need for use of special methods of prediction of genetic values in relation to all the candidate individuals as the best strategy for increasing the efficiency of coffee breeding (Resende et al. 2001, Petek et al. 2008). In methodological terms, the great utility and flexibility of mixed models method should be stressed, which has made a complete estimate and prediction possible, in a situation of great imbalance of data since $57.25 \%$ of the plants were not able to survive in an infested area by $M$. paranaensis. Four hundred seedlings were initially planted, and only 229 plants were evaluated. This leads to maximization of genetic gain through selection, allowing the genetic breeding program to be carried out with a view toward resistance to $M$. paranaensis.

For the purpose of knowing the changes which occurred in the traits studied, involving associations of an inherited nature so that they could be used in guiding the breeding program with a view toward resistance to $M$. paranaensis, the genotypic correlation among the traits studied was estimated (Table 5). It is observed that the correlations among all the traits studied were positive, significant and of high magnitude, ranging from 0.78 to 0.94 . The significant positive correlation between the first yield, stem diameter and number of plagiotropic branches in coffee plants were reported by other authors (Bonomo et al. 2004, Martinez et al. 2007, Carvalho et al. 2010).

Characterization of the reaction of the genotypes to the nematode by grades also showed positive correlation with yield. This indicates the possibility of obtaining genetic gains through selection based on symptomatological characterization of plants in field conditions, and valid for application of the grading scale, which was used by Carneiro (1995) to evaluate coffee plants at 36 months from planting in an area infested by $M$. incognita. Thus, the results confirm the usefulness of this scale also for coffee plants in initial development, in an area infested by M. paranaensis, constituting a tool for early evaluation of plant reaction to the nematode.

\section{ACKNOWLEDGEMENTS}

To the National Science and Technology Institute (INCT-Café), to the Coffee Research Consortium, and to the Research Support Foundation of the State of Minas Gerais (FAPEMIG), for financial support for the project; and to the owner of Guaiçara Farm, for making the experimental area available. We also thank CNPq and FAPEMIG for research fellowship.

\section{Seleção de progênies de café para a resistência ao nematoide Meloidogyne paranaensis em área infestada}

Resumo - Objetivou-se neste trabalho selecionar progênies de Coffea arabica para resistência à M. paranaensis em área cafeeira infestada usando a abordagem de modelos mistos de Henderson. Quarenta e um genótipos foram selecionados no Banco Ativo de Germoplasma de Café de Minas Gerais e avaliados individualmente quanto ao diâmetro de caule, número de ramos plagiotrópicos, caracterização da reação dos genótipos ao nematoide e produção por planta. Houve variabilidade genética entre os genótipos estudados para todas as características avaliadas, e entre as populações estudadas para as características produção e caracterização da reação dos genótipos ao nematoide, indicando possibilidades de obtenção de ganhos genéticos pela seleção nesta população. As correlações genotípicas entre todas as características estudadas foram significativas. Cafeeiros da população de Híbrido de Timor UFV 408-01 e progenies $F_{3}$ derivadas do cruzamento entre Catuai Vermelho e Amphillo MR 2161 foram os mais promissores em área infestada por $M$. paranaensis.

Palavras-chave: Coffea arabica, melhoramento, valor genético aditivo, correlação, nematoide das galhas.

\section{REFERENCES}

Alpizar E, Etienne H and Bertrand B (2007) Intermediate resistance to Meloidogyne exigua root-knot nematode in Coffea arabica. Crop Protection 26: 903-910.

Anthony F, Topart P, Astorga C, Anzueto F and Bertrand B (2003) La resistencia genética de Coffea spp. a Meloidogyne paranaensis: identificación y utilización para la caficultura latinoamericana. Manejo Integrado de Plagas y Agroecología 67: 5-12.

Boisseau M, Aribi J, Sousa FR, Carneiro RMDG and Anthony F (2009) Resistance to Meloidogyne paranaensis in wild Coffea arabica. Tropical Plant Pathology 34: 38-41.

Bonomo P, Cruz CD, Viana JMS, Pereira AA, Oliveira VR and Carneiro
PCS (2004) Avaliação de progênies obtidas de cruzamentos de descendentes do Híbrido de Timor com as cultivares Catuaí Vermelho e Catuaí Amarelo. Bragantia 63: 207-219.

Carneiro RG (1995) Reação de progênies de café Icatu a Meloidogyne incognita raça 2, em condições de campo. Nematologia Brasileira 19: 53-59.

Carneiro RMDG and Almeida MRA (2001) Técnica de eletroforese usada no estudo de enzimas dos nematoides de galhas para identificação de espécies. Nematologia Brasileira 25: 35-44.

Carneiro RMDG, Mesquita LFG, Goncalves W and Pereira AA (2008) Pathogenicity of Meloidogyne spp. (Tylenchida: Meloidogynidae) from Brazil and Central America on two genotypes of Coffea arabica. Tropical Plant Pathology 33: 309-312. 
Carvalho AM, Mendes ANG, Carvalho GR, Botelho CE, Gonçalves FMA and Ferreira AD (2010) Correlação entre crescimento e produtividade de cultivares de café em diferentes regiões de Minas Gerais, Brasil. Pesquisa Agropecuária Brasileira 45: 269-275.

Castro JMC, Campos VP, Pozza EA, Naves RL, Andrade Júnior WC, Dutra MR, Coimbra JL, Maximiniano C and Silva JRC (2008) Levantamento de fitonematoides em cafezais do Sul de Minas Gerais. Nematologia Brasileira 32: 56-64.

Chiorato AF, Carbonell SAM, Dias LAS and Resende MDV (2008) Prediction of genotypic values and estimation of genetic parameters in common bean. Brazilian Archives of Biology and Technology 51: $465-472$.

Cilas C, Montagnon C and Bar-Hen A (2011) Yield stability in clones of Coffea canephora in the short and medium term: longitudinal data analyses and measures of stability over time. Tree Genetics and Genomes 7: 421-429.

Costa RB, Resende MDV, Gonçalves PS, Roa RAR and Feitosa KCO (2010) Predição de parâmetros e valores genéticos para caracteres de crescimento e produção de látex em progênies de seringueira. Bragantia 69: 49-56.

Cruz CD and Carneiro PCS (2003) Modelos biométricos aplicados ao melhoramento genético. Editora UFV, Viçosa, 585p.

Cruz CD (2006) Programa Genes: biometria. Editora UFV, Viçosa, 382p.

Freitas ZMTS, Oliveira FJ, Carvalho SP, Santos VF and Oliveira JP (2007) Avaliação de caracteres quantitativos relacionados com o crescimento vegetativo entre cultivares de café arábica de porte baixo. Bragantia 66: $267-275$.

Furlani RCM, Moraes MLT, Resende MDV, Junior EF, Gonçalves PS, Filho WVV and Paiva JR (2005) Estimation of variance components and prediction of breeding values in rubber tree breeding using the REML/BLUP procedure. Genetics and Molecular Biology 28: 271-276.

Gichimu BM and Omondi CO (2010) Early performance of five newly developed lines of Arabica Coffee under varying environment and spacing in Kenya. Agriculture and Biology Journal of North America 1: 32-39.

Gonçalvez W, Ferraz LCB, Lima MMA and Silvarolla MB (1996) Reações de cafeeiros às raças 1,2 e 3 de Meloidogyne incognita. Summa Phytophatologica 22: 172-177.

Gonçalves W, Silvarolla MB (2007) A luta contra a doença causada pelos nematoides parasitos do cafeeiro. O Agronômico 59: 54-56.

Henderson CR (1984) Applications of linear models in animal breeding. Unviersity of Guelph, Ontario, 462p.

Ito DS, Sera GH, Sera T, Santiago DC, Kanayama FS and Grossi L del (2008) Progênies de café com resistência aos nematoides Meloidogyne paranaensis e raça 2 de Meloidogyne incognita. Coffee Science 3: 156-163.

Kanayama FS, Sera GH, Sera T, Mata JS, Ruas PM and Ito DS (2009)
Progênies de Coffea arabica cv. IPR 100 com resistência ao nematóide Meloidogyne incognita raça 1. Ciência e Agrotecnologia 33: 13211326.

Martinez HEP, Augusto HS, Cruz CD, Pedrosa AW and Sampaio NF (2007) Crescimento vegetativo de cultivares de café (Coffea arabica L.) e sua correlação com a produção em espaçamentos adensados. Acta Scientiarum Agronomy 29: 481-489.

Mata JS, Sera T, Altéia MZ, Azevedo JA, Fadelli S, Petek MR, Triller C and Sera GH (2002) Resistência de genótipos de cafeeiro (Coffea arabica L.) de São Jorge do Patrocínio ao nematoide Meloidogyne paranaensis (EMN2001.07). SBPN Scientific Journal 6: 34-36.

Matiello JB, Santinato R, Garcia AWR, Almeida SR and Fernandes DR (2010) Variedades de café. In Matiello JB, Santinato R, Garcia AWR, Almeida SR and Fernandes DR (Eds.) Cultura de café no Brasil - manual de recomendações. MAPA/PROCAFÉ, Rio de Janeiro/ Varginha, p. 63-98.

Petek MR, Sera T and Fonseca ICB (2008) Predição de valores genéticos aditivos na seleção visando obter cultivares de café mais resistentes à ferrugem. Bragantia 67: 133-140.

Resende MDV (2002) Genética biométrica e estatística no melhoramento de plantas perenes. Embrapa Informação Tecnológica, Brasília, 975p.

Resende MDV (2007) Software SELEGEN-REML/BLUP: sistema estatístico e seleção genética computadorizada via modelos lineares mistos. Embrapa Florestas, Colombo, 359p.

Resende MDV, Furlani-Junior E, Moraes MLT and Fazuoli LC (2001) Estimativas de parâmetros genéticos e predição de valores genotípicos no melhoramento do cafeeiro pelo procedimento REML/BLUP. Bragantia 60: 185-193.

Ribeiro RCF, Pereira AA, Oliveira CH and Lima RD (2005) Resistência de progênies e híbridos interespecíficos de Coffea arabica e Coffea canephora a Meloidogyne exigua. Nematologia Brasileira 29: 1-16.

Roberts PA (2002) Concepts and consequences of resistance. In Starr JL, Cook R and Bridge $\mathrm{J}$ (eds.) Plant resistance to parasitic nematodes. CABI, Wallingford, p. 23-42.

Rocha RB, Vieira AH, Gama MMB and Rossi LMB (2009) Avaliação genética de procedências de bandarra (Schizolobium amazonicum) utilizando REML/BLUP (Máxima verossimilhança restrita/Melhor predição linear não viciada). Scientia Forestalis 37: 351-358.

Sera GH, Sera T, Fonseca ICB, Ito DS (2010) Resistência à ferrugem alaranjada em cultivares de café. Coffee Science 5: 59-66.

Sera GH, Sera T, Ito DS, Mata JS, Doi DS, Azevedo JA and Ribeiro-Filho C (2007) Progênies de Coffea arabica IPR 100 resistentes ao nematoide Meloidogyne paranaensis. Bragantia 66: 43-49.

Sera GH, Sera T, Mata JS, Alegre CR, Fonseca ICB, Ito DS, Kanayama FS and Barreto PC (2009) Reaction of coffee cultivars Tupi IAC 1669-33 and IPR 100 to nematode Meloidogyne paranaensis. Crop Breeding and Applied Biotechnology 9: 293-298.

Sera T, Mata JS, Ito DS, Doi DS, Sera GH, Azevedo JA and Cotarelli 
Selection of coffee progenies for resistance to nematode Meloidogyne paranaensis in infested area

VM (2004) Identificação de cafeeiros resistentes aos nematoides Meloidogyne paranaensis e $M$. incognita raças 2 e 1 em populações de Icatu (Coffea arabica). SBPN Scientific Journal 8: 20-25.
Vencovsky R (1987) Herança quantitativa. In Paterniani E and Viegas GP (eds.) Melhoramento e produção de milho. Fundação Cargill, Campinas, p. 137-214. 